\title{
"Selfish, Short-Sighted, and Sanctimonious": Bowdoin College, Alex Schulten, the 1.600 Rule and the Welch Scholarship
}

\author{
Dan Covell \\ Western New England University
}

\begin{abstract}
In this article, the author examines passage of the National Collegiate Athletic Association's (NCAA) 1.600 Rule in 1965 and the ramifications of that mandate. In drawing from administrative letters and memoranda available through the George J. Mitchell Department of Special Collections and Archives, the author investigates Bowdoin College's response to the 1.600 Rule, the influence of the College's confrontation with the NCAA on its athletes and their ability to compete at the national level, and how the conflict shaped the institution's operations. Ramifications for Bowdoin College and the NCAA are discussed.
\end{abstract}

Keywords: academic eligibility, financial aid, NCAA

For the first century or so of American intercollegiate athletic competition, most institutions maintained a separate admissions standard for athletes, choosing to admit any athlete without abiding by any stated admissions policies. Since the inception of the National Collegiate Athletic Association (NCAA) in 1905 as the first national governing body for the enterprise, member schools have waged a constant struggle to come to grips with the thorny issue of academic eligibility. This has usually occurred through the NCAA's legislative mechanisms, which at various times has pitted against each other some combinations of member institutions, coaches, athletes, school presidents, politicians, and social critics. The twin goals of this process have been to determine (a) what exactly the appropriate level of academic achievement should be required of prospective student-athletes, and (b) how these factors should be assessed first in the admissions process, and then again as student-athletes pursued their studies once enrolled.

These are the dual factors that would eventually become known as initial (preenrollment) and continuing (postenrollment) eligibility.

The NCAA assumed gradually and piecemeal the role of arbiter for initial eligibility academic requirements, but the standardization that occurred as the NCAA attempted to level this playing field runs counter to trends in American 
higher education. As John Thelin observed, higher education "is remarkable for its decentralized arrangement characterized by institutional autonomy, voluntary association, and relatively little government regulation" (1996, p. 10). In addition, the legitimization of intercollegiate athletics is made through eligibility rules, which as noted by Helman, provide "standards that tether commercial athletics to the educational purposes of a higher education" (1989, p. 237). The constant friction over what constitutes acceptable benchmarks by which student-athletes are to be deemed eligible has led to an evolving set of evaluative criteria, with a varying corresponding degree of effectiveness in assuring that those who participate in athletics are not merely athletes, but also truly students.

In the mid-1960s, conflict over academic eligibility issues emerged to the most significant level in NCAA history with the passage of the 1.600 Rule, which prescribed the eligibility of student-athletes at NCAA member institutions to an unprecedented degree. The rule established that a prospective student-athlete must attain specific marks in grade-point average and standardized test scores to be eligible to compete and to receive athletically related financial aid. While some member institutions bristled at the passage of this mandate, only a handful, most notably Bowdoin College, chose to denounce the rule publicly and refused to submit to the directive. This action meant that Bowdoin student-athletes would not be eligible to participate in NCAA championship events, which meant that standout Bowdoin hammer thrower, Alex Schulten, would be barred from a very real chance to win the event at the 1966 indoor track and field championships.

This research, based on administrative letters and memoranda available through the George J. Mitchell Department of Special Collections and Archives at Bowdoin College, as well as newspaper reports and other publications from the period, will reconstruct the events that led to this decision by Bowdoin, examines how Bowdoin administrators attempted to manage the implications of their decisions regarding the 1.600 rule, and how the issue was ultimately resolved. While Bowdoin officials claimed institutional autonomy as the reason for their actions, this research shows that issues relating to athletically related financial aid, something the school claimed it did not offer, was a key factor in driving college officials to oppose 1.600. This research also seeks to put into context how the NCAA was establishing greater influence on the mission, goals and operational areas of its member institutions, the immediate impact of this shift, and the implications of these influences today.

\section{The 1.600 Rule}

As noted previously, there are two components to the determination of academic eligibility for student-athletes: initial (preenrollment) and continuing (postenrollment). Initial eligibility refers to the determination of the appropriate level of academic achievement for incoming prospects. The demise of the Sanity Code in the late 1940s in part led to the establishment of formal athletic scholarships. To this point, Sack and Staurowsky state that "with an athletic scholarship system in place, it became absolutely imperative for the NCAA to establish a minimum academic level for awarding scholarships. To not do so would have fueled public cynicism that already surrounded professionalized college sports" (1998, p. 96). The bulk of NCAA legislation over the next decade dealt with recruiting and athletic aid issues, and it was left again to conferences to create and enforce aca- 
demic standards, although in 1959 the NCAA did strengthen academic eligibility standards for their championship competitions, requiring that student-athletes be enrolled in a full course of study of no fewer than 12 semester or quarter hours (Falla, 1981).

Also in 1959, an initial call for the NCAA to adopt an association-wide initial eligibility academic requirement came forth from Stanford University's Rixford Snyder (the school's director of admissions and Faculty Athletics Representative to the Pacific Coast Conference). According to Smith (2011), Snyder told delegates at the '59 NCAA Convention that the best predictors for academic success in college were high school grades and scores on standardized tests, and when the two were weighed together, the prediction on college success was greater still. In 1962, the NCAA established a committee, lead by Atlantic Coast Conference commissioner James Weaver, to determine a formula for "predicting academic success" for those student-athletes who received athletic aid (Smith, 2011, p. 128).

As a result, the NCAA membership approved a national standard in 1965, set to take effect on January 1, 1966, that required an incoming athlete to achieve a predicted first-year college GPA of at least 1.600 (on a 4.0 scale) before the prospect could receive athletically related aid, based on a computation of a prospect's class rank and standardized test score on either the Scholastic Aptitude Test (SAT) or the test administered by American College Testing (ACT). The so-called "1.600 Rule" was the association's first-ever minimum academic standard for the awarding of athletically related financial aid. The prospect's standardized test scores were also used in determining eligibility, which according to former NCAA Executive Director Walter Byers (who held that position at the time 1.600 was passed), "provided an essential national comparative standard" (1995, p. 158).

\section{The Form of Opposition: Bowdoin College}

That opposition to the 1.600 Rule was voiced is not surprising, for, much like with the avowals of noncompliance expressed in response to the Sanity Code, many schools saw the rule as a threat to their competitiveness. But criticism and outright defiance came from unexpected sources as well, namely the members of the Ivy League and some other so-called "selective" schools. These schools-which enjoyed public recognition and prestige as the perceived leading academic institutions in the United States-stated that they were unwilling to submit to NCAA control over their admissions processes and academic autonomy, and chose to denounce the measure publicly. But one school would become more active and more public than any other in fighting 1.600: Bowdoin College. A private, all-male college founded at the close of the eighteenth century in Brunswick, Maine, Bowdoin had evolved into a small (fewer than a thousand students), four-year, academically selective liberal arts institution still all male.

When 1.600 passed and became effective as Article 4, Section 6-(b) of the NCAA's Bylaws, Bowdoin College issued a press release stating that the school "will continue determine its admissions policies and financial aid programs to best serve the interests of Bowdoin students, and thus cannot comply with the new rule" ("Bowdoin College," 1966, p. 1). The press release stated further that in a letter to NCAA President Everett D. ("Eppy") Barnes, Bowdoin President James S. Coles wrote: 
Bowdoin College does not differentiate between 'student-athletes' and other students and consequently believes that the (required certification) form involved has no application to us. All our students are admitted by our own policies and procedures and the awards of scholarship aid are determined by us on the basis of need and performance. We have no intention of altering this procedure ("Bowdoin College," 1966, p. 2).

Also cited in the press release, Bowdoin athletic director Malcolm E. ("Mal") Morrell, who no doubt was well aware of the impending applications of the rule and its potential impacts, said of 1.600: "It seems unbelievable that the NCAA Council would promote legislation that could cause many of its high standard institutions to give up memberships they have held for years" ("Bowdoin College," 1966, p. 2).

The press release then stated that based on the action, Bowdoin would be barred from sending athletes to NCAA-sanctioned track and swimming championships (the College, under an agreement with several other similar New England colleges, did not permit any team sports to participate in NCAA postseason events). Thus, Bowdoin's Alex Schulten would be unable to participate in the hammer-throw in the upcoming NCAA indoor track and field championships, an event he had won at the outdoor championships in 1964 ("Bowdoin College," 1966). Schulten was seeded Number 1 in the Association's indoor meet scheduled for Detroit in midMarch (Litsky, 1966; "N.C.A.A. championships," 1966). Of the implications of the College's decision, the Bowdoin Alumnus, the College-published magazine for alumni, wrote: "If the road to hell is indeed paved with good intentions, the National Collegiate Athletic Association holds the construction contract ... Most directly affected by the ban will be Alex Schulten '66" ("Revolt," 1966, p. 5).

\section{Alex Schulten: The Direct Victim of Bowdoin's Actions}

As a sophomore in 1964, Frederick Alexis "Alex" Schulten won the NCAA Championship in the outdoor hammer throw with a toss of $191 \mathrm{feet}, 6$ inches, and earned AAU All-American recognition in both the collegiate and university divisions. Later that summer, Schulten was a finalist at the United States Olympic Trials, just missing out on an Olympic berth for the 1964 Tokyo Summer Games. As a junior, Schulten continued to excel, going undefeated in the 35-pound weight throw and capturing the Indoor College Championship. Again he was undefeated in the hammer throw outdoors, earning AAU All-American honors and notching the top collegiate throw of the year with a school record 202 feet, 11 inches-a mark that still stands. When he graduated, Schulten held every school record in the hammer throw and 35-pound indoor weight throw (Calhoun, 1993; "F. Alexis," 2009).

While Schulten was clearly a world-class athlete, there was early evidence that Bowdoin officials were less than enthused with promoting and supporting his efforts. The College opted not to aid Schulten with his expenses and travel for the several collegiate championship meets and the 1964 Olympic Trials, a decision which was met with derision, as demonstrated in an op-ed piece in the Bowdoin Orient, the campus student newspaper (Pappas \& Graham, 1964). Nonetheless, the College was still keen to garner some measure of connectedness with Schulten's success. Schulten was pictured on cover of March 1965 Bowdoin Alumnus having just com- 
pleted a throw in a meet against Boston University. The campus newspaper kept informing its readers of Schulten's continuing development in 1965, and continued to lobby for support for Schulten to travel to significant meets (Blankman, 1965).

The question of why administrators at the College demonstrated ambivalence toward the achievements of Schulten could be addressed by examining the background of Bowdoin's president, James Stacey ("Spike") Coles. Coles was not an alumnus of Bowdoin-unlike his predecessor, the long-serving Kenneth C. M. Sills, who presided at the helm of the College from 1917 to 1952. Athletics, by Coles' own admission, was not an area of expertise for the president, for as late as 1966, Coles would describe himself to Williams College president John Sawyer as "a babe in the woods with respect to athletics" (Coles, 1966c, p. 1). He had, though, served as Brown University's representative to the Ivy League Eligibility Committee while serving as Acting Dean there. That notwithstanding, Coles was under no illusion as to the role of managing athletics issues, as evidenced in a letter written to Coles early in his presidency by Bowdoin's venerable athletic director Mal Morrell:

You told me yesterday, and I am sure that it is true, that the athletic problem causes the President more trouble than all of the other departments of the College. I suppose one reason that this is true is because in this field of experience the College is in open competition and the results are known to the public (Morrell, 1955, p. 2).

On the surface, it may have appeared that in 1966 Bowdoin's institutional approach to athletics remained as it had been in 1952 when Coles took office, but there were issues at play in the specific Bowdoin and general national intercollegiate athletics environments during Coles' presidency_public scrutiny being just one of the factors - that tested his and the College's ability to manage athletics issues effectively. The 1.600 Rule and its impact on Schulten and other operational areas of athletic management-occurring just a year before Coles' leaving the post of president—would prove to be a significant challenge.

\section{Opposition to 1.600 Solidifies: Bowdoin's Administrative Responses}

In early February 1966, a week after the College issued the noncompliance press release, Coles wrote a confidential memo to AD Morrell noting that the presidents of Bowdoin's Pentagonal Agreement peer schools (Amherst, Wesleyan University and Williams College; the grouping originally included a fifth school-Dartmouth College) would be discussing 1.600 at a meeting later that month. The grouping was not a formal league but affiliated based on a common agreement concerning athletic policies. Coles stated to Morrell that Amherst "has not gone along with this rule," and that Wesleyan "is now in the process of reviewing its position on the rule" (Coles, 1966a, p. 1). Coles proceeded to deconstruct and to criticize the rule in the memo to Morrell, stating the rule meant that "if a student-athlete fails to meet the 1.600 requirement, aid must be withdrawn until the student attains the required grade point average. So far as I can see, this is a rule drawn more for the advantage of the institution than for the student-athlete" (Coles, 1966a, p. 1, emphasis added). 
Based on his conceptual misgivings about the fairness of 1.600 , Coles proceeded to parse out a way to avoid its application. Citing a memo from the NCAA's Barnes dated October 8, 1965, which spelled out that the rule was "applicable to student-athletes first entering member institutions January 1, 1966 and thereafter," Coles noted that current Bowdoin students would not be affected by this rule. "We could well claim," he wrote Morrell, "that since this is the case, such men should be permitted to compete, even though the institution has not indicated its intention to enforce such rule for men who enter the College after January 1, 1966" (Coles, 1966a, p. 1).

Coles ended the memo with the threat:

Should the NCAA not change its position, it might be very much worthwhile for the Pentagonal Colleges, along with the Ivy League Colleges, to consider withdrawing from the NCAA, to form their own association with their own championships in individual sports to be run concurrently with the NCAA championships (Coles, 1966a, p. 1).

The terms used and intent of this last phrase are particularly illustrative. Coles is quite specific and intentional in using the term "individual sports," since the Pentagonal Agreement did not permit team sports to participate in NCAA championships. This restriction would continue to cause friction on the Bowdoin campus for subsequent decades. In addition, such an arrangement would continue to allow the rare athlete like Schulten to shine on a more national stage, as well as open up slots for more Bowdoin athletes, since a championship event drawing from fewer schools would likely lead to more available slots for competitors from Bowdoin. The alternative model proposed by Coles, with his Ivy League background (having attended Columbia University and taught and served as an administrator at Brown before taking the helm at Bowdoin), also expresses the effort of Bowdoin and other peer schools in seeking to augment institutional prestige through a closer affiliation with the elite Ivies. The question unanswered in Coles' scheme is what benefits would the Ivies gain through turning away from NCAAs to align with Bowdoin and the Pentagonals. Such a move would likely be viewed as athletic diminution on the part of the Ivies by most observers, with potentially damaging impacts to competitiveness and spectator interest.

To garner support for his position, Coles sent copies of the College's noncompliance press release to presidential colleagues around the Northeast. In response, Bucknell University President Charles Watts noted that "we are contemplating similar action ... I see that Colgate (University) has agreed to it, which surprises me a little bit, as has Lehigh (University). I will let you know what we decide to do" (Watts, 1966, p. 1). Colgate's president, Vincent Barnett, Jr., wrote Coles and noted that "Williams, Wesleyan and Trinity (College in Connecticut) have indicated their adherence to the rule. It seems to me there is room for some difference of opinion here, and I hope the matter can be ironed out in some way that avoids an open split" (Barnett, 1966, p. 1).

But a spilt seemed to be in the offing, and the NCAA was looking to head it off by giving Bowdoin and 56 other member schools (including the Ivies, Amherst College, Middlebury College, Hamilton College, and the Massachusetts Institute of Technology) a one-week extension to February 22 to prove compliance with 1.600 
(Middlebury would also later, like Bowdoin, refuse to comply). Wiles Hallock of the NCAA noted that the extensions were granted "because (the schools) have had correspondences with the NCAA office on the problem and in some cases it is a matter of technical difficulties" (White, 1966, p. 14). But the Ivy League insisted it would not fill out the required forms for compliance and was also threatening to resign over the issue (White, 1966). Two days after that, the Ivies indicated compliance (although the schools never filled out the proper forms), probably to preserve the league's slot in the NCAA's men's basketball tournament ("Ivy League to accept," 1966).

But a week later, the University of Pennsylvania and Yale University were deemed ineligible nonetheless for NCAA postseason events because the schools refused to comply ("Ivy League drops," 1966). The actions of the Ivies would seem to have bolstered Bowdoin's position on 1.600, as some would have viewed Bowdoin favorably if the institution were perceived to be acting like the Ivies. Pentagonal partner Williams College was also not complying, furthering Bowdoin's stance.

In late February 1966, NCAA President Barnes wrote to Sports Illustrated in a response to an article in which the magazine wrote critically of 1.600. Barnes stated:

The legislation simply states that if a college intends to compete with its sister institutions for national championship honors, it should require a minimum 1.6 average of students who are receiving financial assistance based in any part on athletic ability before they may engage in intercollegiate activity (Barnes, 1966, p. 75).

Coles responded to Barnes soon thereafter that "scholarships (at Bowdoin) are granted only on the basis of (students') academic promise ... (and) are granted only on the basis of determined financial need and academic ability." Coles went on to state, "No distinction is made with respect to participation or non-participation in intercollegiate athletics.... We recognize that the policies outlined above would be in conformity with the standards of academic progress and performance expected by the NCAA of men participating in intercollegiate athletics." Accordingly, reasoned Coles, Bowdoin College students should be able participate in NCAA sponsored championships (Coles, 1966b, pp. 1-2).

The nature of Coles' response would seem to have put the issue to rest. In his response to Barnes, Coles was stating flatly that Bowdoin gave no athletic aid; therefore, compliance with 1.600 should have been a simple matter. But Bowdoin's stated approach to athletic aid versus the school's actual practices would prove to be unaligned.

\section{Schulten's NCAA Fate}

While campus sources and College administrators provided a wealth of comments on the 1.600 issue, the mainstream local press did not. The Press Herald, published in Portland, located 25 miles south of Brunswick in Maine's largest city, did run three UPI wires stories on the 1.600 issue as it impacted Pennsylvania and the Ivies (February 25, 26 and March 5). On March 10, the paper ran one of a very few mentions of 1.600 as it impacted Bowdoin, citing comments from a Bowdoin administrator made at an end-of-season banquet. It stated that Nathaniel C. Kendrick, 
dean of the College, had told a gathering of Bowdoin athletes at the winter sports awards dinner that College "could not justifiably turn over to the National Collegiate Athletic Association its authority to rule on admission, eligibility, or scholarship awards to students. Dean Kendrick predicted, 'I don't think this controversy is finished by a long shot." "The Press Herald also cited that Kendrick admitted that Schulten would be among those banned. "Alex Schulten never got a scholarship from Bowdoin," Kendrick added at the gathering ("Dean reaffirms," 1966, p. 22).

What is interesting to note from these comments is whether Kendrick was making general remarks, or was responding to comments from the audience or from a reporter. It is also equally intriguing to note that Kendrick made specific reference to Schulten in offering a denial that he received a "scholarship." Aside from the fact that may have been offering personal information pertaining to Schulten's financial status, it would seem to indicate that the concept of athletic aid was the crux of the fight from compliance with 1.600.

Meanwhile, as Schulten's NCAA fate was being sealed, other voices on campus were falling in line with the administrative stance. In March, the student newspaper (which may or may not have had full editorial control, since the College's dean of the students and future acting college president, Athern P. Daggett, was a member of the paper's publishing board, along with members of the Orient staff of undergraduates), reported on the progress of the issue, noting that Bowdoin was in step with Williams and the Ivies. The paper cited William Morgan, AD Mal Morrell's assistant, who commented that the College would "resolve its differences with the National Collegiate Athletic Association following whatever pattern is worked out with by the Ivy League" (Rice, 1966b, p. 4). The paper also noted that four other schools (including Williams) had specifically announced that they would not comply. "The appearance of Williams on this list is significant," wrote the paper. "Williams has chosen to definitely buck the NCAA pressure ... As Mr. Morgan said, 'I think they (the NCAA) bit off more than they could chew.' This, we think, is entirely possible" (Rice, 1966a, p. 4).

On the same date as Kendrick's awards dinner comments, the Orient published an additional commentary on 1.600, again expressing its perception that Bowdoin and Ivies could bring the NCAA to heel. The writer again missed the athletic aid point while offering a prediction that the issue might bring an end to the NCAA's governing powers. The paper continued that Bowdoin's position in this dispute will in essence be that of the Ivy League, and noted that Dean Kendrick "feels that the NCAA will have to back down." The consequence of the "stalemate," stated Kendrick, was that Alex Schulten would not be entered in the upcoming NCAA championships. Wrote the paper: "We again must express our support for the College's position ... The NCAA certainly seems, as was noted last week, to have bitten off more than it could chew" (Rice, 1966b, p. 4). The Orient offered a final comment on 1.600 in a brief reference (with no mention of Schulten) in an editorial in its end-of-year issue: "The College's stand on the National Collegiate Athletic Association ruling requiring a grade point average of at least 1.6 in awarding scholarships to 'student-athletes' was commendable, and indicates the College's concern for its students" ("Editorial," 1966, p. 4). No further comments would be made, and no additional clarification offered as to how the College's stance in any way was forwarding a sense of concern for its charges, especially since the refusal to comply came at the expense of Schulten's NCAA title hopes. 
In addition to the documented perspectives published in the student newspaper, the administrative files available in the archives at Bowdoin contain feedback from other stakeholder groups. In June 1966, track coach Frank Sabasteanski forwarded to President Coles a letter Sabasteanski received from a former Bowdoin student track manager, James H. Bradner, Jr., who was attending law school at Ohio State University. The letter Bradner sent was supportive of the College's stand against 1.600 , noting that because of the dispute "perhaps it is inevitable that the scholastically oriented smaller colleges will have to withdraw from the NCAA and form their own athletic association." In also noting that "the average undergraduate at a Big Ten university is just not of the high intellectual caliber of the Bowdoin undergraduate," Brander concluded:

I hope Bowdoin will stick firmly to its present policy regarding the NCAA 1.6 rule ... I wanted the Athletic Department to know that at least one individual enthusiastically supports their conception of athletics and its place in the collegiate atmosphere (Bradner, 1966, p. 1-2).

While Bradner's passion is clearly expressed, it is also intriguing to the degree that it lobbies for Bowdoin to separate from schools like Ohio State and form a new type of association. While this suggestion, as others like it, would never come to pass, it does presage by several years the movement within the NCAA to create the current three division classification system, which, by establishing specific missions and visions for each of the three tiers, would help keep a growing and increasingly disparate association from splintering.

However, other alumni were less than enthused with the College's tack on the issue, as evidenced by the letter published in the Alumnus from Joseph F. Tiede (Class of 1952) from Raleigh, North Carolina. In correctly observing that "The great majority of NCAA-member schools approved the ruling," Tiede opines:

It seems to me that Bowdoin and the other protesting colleges are skirting the issue and thereby punishing their own athletes for no compelling reason. Anyone can see the rule was not aimed at the academic giants, but at schools with questionable standards for athletes (Tiede, 1996, p. 1)

Tiede ends his letter with the question:

Is Bowdoin in the habit of admitting athletes, or any students, who cannot meet the minimum NCAA requirements? That is doubtful. Then why should it object to an effort that would raise the standards that need raising? ... This attitude, in my opinion, is selfish, short-sighted, and sanctimonious (Tiede, 1966, p.1).

Tiede's letter raises several compelling points, especially in its ability to capture a sense of confusion as to why Bowdoin would choose to fight 1.600 and deny athletes like Schulten a chance at athletic success for what he calls "no compelling reason." Like the letter from former track manager and fellow alumnus Bradner, Tiede agrees that an institution like Bowdoin with its academic and athletic directions should not be impeded with the dictates of 1.600. But the actions that Tiede interprets as "selfish, short-sighted, and sanctimonious" would turn out to be focused on covering practices that were more problematic. 


\section{Bowdoin's Post-Schulten Administrative Responses}

In June 1966, after Alex Schulten graduated having missed out on his opportunity to compete at the NCAA championships, Bowdoin's Kendrick responded to an NCAA survey seeking information about potential revisions to 1.600. Kendrick asked the Association to allow institutions "which base financial aid on need and performance but not on athletic qualifications, performance, and participation," to be free to formulate their own admissions policies and standards and to determine their own rules of eligibility:

For college teams as long as these men are regular students in the college ... From our point of view repeal would be better but revision to take care of colleges which do not have 'student athletes' and athletic scholarships would probably be acceptable (Kendrick, 1966, pp. 1-2).

Kendrick - and now it would seem to be some sort of intentional obtusenessagain seems to miss the point about the focus of 1.600 pertaining to those studentathletes who received athletic aid. The 1.600 legislation never restricted a school in its admissions policies and standards, nor did it restrict athlete eligibility. It merely limited athletic aid to those student-athletes who had achieved the predicted 1.600.

In January 1967, Bowdoin's Faculty Committee on Athletics, composed of faculty members and with limited influence and control over athletic policy, held fast to this misguided stance. The committee reported that it had reviewed and approved the position that College "cannot subscribe" to the rule. "The rule does not distinguish between athletic scholarships and general scholarships for which athletics are viewed as simply an extracurricular activity," read the statement. "The desirability of our own scholarship policy being determined by the College in terms of its own objectives seems obvious ("Report," 1967, p. 1).

The wording in this statement supports the notion that Bowdoin did indeed provide aid to students based on athletic ability, regardless of whether it was perceived as something merely to be pursued as an "extracurricular activity." Such a distinction may have meant something to this group, but in terms of NCAA compliance, it was a specious distinction.

\section{The NCAA Offers a Loophole}

A year after the initial conflict over 1.600, the Ivies and the NCAA settled their issues in February of 1967 (just before that year's NCAA men's basketball tournament) after "personal conversations" between Yale president Kingman Brewster and NCAA President Marcus Plant, which "emphasized how the Ivy Group admissions policies are such that they do not admit any students, athletes or not, who would fall below the 1.600 prediction" ("An interim agreement," 1967, p. 1). Following this, it was Coles rather than Kendrick who wrote Plant seeking "a copy of the agreement which the NCAA has reached with the institutions in the Ivy Group. Would this same agreement be available to Bowdoin College ... should we find it not inconsistent with basic institutional policy?"(Coles, 1967b, p. 1) Plant wrote back that Bowdoin needed to submit a statement that the College "does not accept any student, athlete or not, who would fall below the 1.600 prediction," and confirm 
that sophomores must earn a grade point average of at least 1.6 on a 4.0 scale to be eligible for intercollegiate athletic practice or competition "or if he is to receive financial aid in which athletic ability is considered in any degree in making the award" (Plant, 1967a, p. 1).

A key distinction offered by Plant was that between the initial and continuing eligibility components of 1.600 , where a school had to certify that no students would be accepted nor allowed to compete if they did not meet the prediction threshold, and the issue of athletically related aid. Plant's response differs from the clarification offered by NCAA President Barnes to Sports Illustrated after the measure went into effect. This new interpretation, therefore, allowed first the Ivies then Bowdoin to skirt the issue of athletic aid and certify instead that they neither admitted nor allowed to compete any student-athlete who fell below the 1.600 threshold. And since Bowdoin and the Ivies had made such a public stance of their academic selectivity, it would seem that the NCAA established this loophole for them to step through.

"Thank you for your thoughtful and clear letter of 1 March 1967," Coles replied two days later (after feedback in a memo from AD Morrell). He continued:

Had this procedure been set forth last year, it would have solved the problem of participation in the Hammer Throwing Championship ... Had Alex Schulten not graduated last June, it would permit him to participate this year. But small colleges like Bowdoin have few athletes of championship caliber (Coles, 1967c, pp. 1-2).

Coles continued that for future possible participation in NCAA championships, Bowdoin would submit a statement under Point 1 of the alternate procedure outlined in Plant's letter that Bowdoin does not accept any student, "athlete or not," who would fall below the 1.600 prediction on the NCAA national table (Coles, 1967c, pp. 1-2).

But Coles still did not fully embrace the waiver Plant offered, stating that in respect to Point 2, the College would not confirm that a continuing student must earn a grade point average of at least 1.600 to be eligible for intercollegiate athletic practice or competition. Coles explained that this approach "determined on what we believe to be sound educational grounds, that any student registered in college is eligible for intercollegiate practice or competition, provided only that students who are on academic probation will be required to meet all academic appointments." This policy permitted participation in practice and home games, but prohibited participation in games away from home, if absence from classes is involved. "On the basis of experience at Bowdoin," Coles continued, "and in my own experience as a Dean before coming to Bowdoin, it seems clear that an active vigorous young man, long accustomed to intensive athletic activity, will study better and work better if that activity can be continued, than is the case when he is prohibited from all such activity." In closing, Coles hoped that "it may be possible for the NCAA to resolve this problem in such a fashion that all of its member institutions may have full and equal participation in all NCAA-sponsored championships" (Coles, 1967c, pp. 1-2).

Coles was still holding out against the NCAA's membership-approved interpretations of 1.600 in stating that the College would allow any student-athlete to 
compete regardless of his GPA. He was, however, being disingenuous in claiming that he hoped "that all of its member institutions may have full and equal participation in all NCAA-sponsored championships," since Bowdoin, as part of the Pentagonal Agreement with Amherst, Wesleyan and Williams, did not permit any team sport to participate in any postseason competitions whatsoever, including NCAA championships. The signatory schools had formally approved this postseason team sport ban in 1961, with a substantial amount of debate concerning the ban occurring up to that point, much of it in the form of complaints from students, coaches, and athletic directors.

The team ban rule was never embraced by the athletic rank and file at member schools, as evidence by a June 1964 meeting of the four Pentagonal ADs at Bowdoin. The ADs reported that all coaches of each of the four schools wanted the rule reviewed and changed, as did two of the ADs (Morrell of Bowdoin and E.E. Richardson of Amherst) (Thoms, 1964).

In response to these grumblings, in early ' 67 (at the same time he was playing things out with Marcus Plant and the NCAA) Coles wrote the other Pentagonal presidents with the following: "We still have complaints from our coaches and undergraduates with respect to post-season championships. One might wonder whether or not the pain this causes is worth the possible gains from this particular rule" (Coles, 1967a, p. 1). Williams president Sawyer, who had also chosen not to comply with 1.600 certification, responded to Coles in favor of postseason play, noting that it "has a great deal in its favor as a general policy of agreement ... in contrast to the build-up of pressures that comes on any one institution at the time a winning team builds up steam for a post-season trip" (Sawyer, 1967, p. 1).

While the 1.600 Rule was in theory a separate issue from that of postseason competition, the banning of Schulten because of it did add fuel to the fire surrounding the team sport ban. Initially, some of the flak was related to the perceived double-standard that individual sport athletes could compete in postseason contests, while team sport athletes could not. While the issue would not have been of much significance previously, the fact that the Association was beginning to hold "College Division" championships meant that Bowdoin teams now had a more realistic shot at postseason qualification. The issue would become more problematic with the creation of the formal Division III classification in 1973, and would continue to cause trouble for Bowdoin and its eventual New England Small College Athletic Conference (NESCAC) members. The issue simmered until the team sport ban was lifted in 1994, and again when presidents sought to reinstate a limitation on appearances a few years later. Nonetheless, it is reasonable to consider that Coles and his presidential colleagues may have been using the 1.600 Rule dispute as a way to bring individual sports under the same prohibition as team sports, while conveniently foisting the blame for it on the NCAA.

\section{Athletically Related Aid at Bowdoin: A Key Factor in the 1.600 Fight}

It is significant to note that Bowdoin officials failed consistently to mark the references to the athletic aid issue outlined by the NCAA's Everett Barnes in his Sports Illustrated letter, and later reinforced by the NCAA's Marcus Plant in March of 1967. In his Sports Illustrated letter, Barnes stated clearly that the rule requires "a 
minimum 1.6 average of students who are receiving financial assistance based in any part on athletic ability" (Barnes, 1966, p. 1). A year later, Plant specifically reinforced this concept in a letter to Coles (Plant, 1967a). It seems like much of the wrangling could have been avoided if Bowdoin, the Pentagonals, and the Ivies if officials at these schools had read the rule's aid component closely and certified that no such aid awards were being issued.

However, comments of Bowdoin's Faculty Committee on Athletics made in early 1967 supports the notion that athletic ability was indeed a factor in determining some aid awards. This issue is highlighted in part by a letter from Yale President Brewster to President Sawyer of Williams written in September 1967. Brewster noted that he and the NCAA's Marcus Plant had been engaged in "informal conversations and correspondence" to see whether the NCAA and the Ivy League could resolve their remaining differences with respect to 1.600 , but that any resolution seemed impossible "especially with respect to (the section) of that legislation covering financial aid and athletic eligibility for students already enrolled" (Brewster, 1967, p. 1).

This would show to be an issue at Bowdoin as well, as evidenced by the creation and maintenance of the Arthur D. and Francis J. Welch Scholarship Fund, established in 1966. The Welch Scholarship, as it would become known, was given by Mr. And Mrs. Edward P. Morgan, Vincent B. Welch (Bowdoin Class of 1938), and his wife, to honor Arthur D. Welch (Vincent's father) and Francis J. (Vincent's uncle) - both of whom were also Bowdoin graduates. It was anticipated that the fund would provide a $\$ 1200$ grant beginning in 1967 , with one new $\$ 1200$ added each year until further notice. The fund was endowed with $\$ 54,000$ in 1967 , and funded through the deed of 42 oceanfront lots in Ocean Beach, Maryland. The qualifications of the Welch Scholarship were first listed in the 1967-1968 Bowdoin College Bulletin, a College publication that served notice of courses offered, admissions policies, as well as other pertinent College information, noting the restriction: "Preference to students athletically adept and from outside New England" (Bowdoin College Bulletin, 1967, p. 75). This was not the only scholarship intended for student-athletes, as the 1967 Bulletin lists one other grant with restrictions that awards be given to the athletically adept: The Class of 1940 Memorial Scholarship, established in 1965, based on a fund totaling over $\$ 15,000$ (Bowdoin College Bulletin, 1967).

At the time the Welch Scholarship fund was established, Coles sent a memorandum to Director of Admissions Richard Moll and Director of Student Aid Walter Moulton outlining Vincent Welch's perspective on the fund. This memo cited Welch's belief that "too high a value cannot be placed on participation in organized freshman, varsity (or junior varsity) competitive squads in contact sports, track and field, and swimming." Welch then put forth that those who would be awarded Welch Scholarships "shall be chosen from among those who are athletically adept and who will contribute significantly throughout a major portion of the school year to the College through athletic competition, as well as in other ways, to the extent of their ability" (Coles, 1966d, p. 1).

Coles' involvement with Welch and his knowledge of the circumstances on which the fund was created leaves no doubt that he was aware that his school was indeed giving athletically related aid, and that the creation of 1.600 called the question as to whether Bowdoin was holding true to its stated policy denouncing such aid. In response to this problem, the language outlining the provisions of the 
Welch Scholarship was amended in 1968 to: "Preference to academically talented students of high character, with leadership potential and athletic proficiency, and from outside New England" (Bowdoin College Annual Catalog, 1968, p. 77). While it could still be argued that the Welch Scholarship was still athletically related aid, this charged was leavened with additional nonathletic requirements. Interestingly, the restrictive language for the other award targeting the athletically adept, the Class of 1940 Memorial Scholarship, remained unchanged.

\section{A Compromise Is Reached}

Toward the end of 1967, the NCAA's Marcus Plant sent out a notice to all member schools noting proposed amendments to 1.600 to be voted on at the Association's 1968 Annual Meeting that January in New York City (Plant, 1967b). The amendment stated that the continuing eligibility portion of 1.600 would not apply to institutions that used the NCAA's national experience tables "or more demanding institutional or conference predictive formulae in (the initial admissions process)." Plant concluded that "such institutions shall be limited only by the official institutional regulations governing normal progress toward a degree for all students as well as any other applicable institutional eligibility rules" ("N.C.A.A. Councilsponsored," 1967, p. 1).

While Bowdoin's administrators had been pushing the NCAA for such exceptions, based on the proposed amendments it was clear that Bowdoin was not alone. The NCAA would be sued several times in conjunction with efforts to overturn 1.600 , although unsuccessfully. The result of the passage of the measure, however, was that the academic caliber of student-athletes improved considerably nationally. Nonetheless, attempts to weaken 1.600 were defeated at almost every convention until 1973 ("New 'triple option,", 1978).

After the Association's meeting where 1.600 was eliminated, new Bowdoin AD Daniel Stuckey reported to Athern Daggett, the former Dean now serving as Bowdoin's acting president: "Bowdoin can set its own policy in regard to financial aid and athletic eligibility, since its prediction tables are more demanding than the national tables" (Stuckey, 1968, p. 1). Dean of the College (and future Bowdoin president), A. LeRoy Greason Jr., was now responsible for matters pertaining to 1.600, and duly supplied the NCAA the College's predictive formula for first-year students via telegram on March 7, 1968. Greason reported that students were admitted to the college on the basis of five factors: performance in college board tests (the SAT and three achievement tests), school records and statement, letters of reference, personal characteristics, and (usually) interviews. "The emphasis may vary as the Faculty Committee passes on each case, but no student is admitted for whom passing work is not expected," Greason stated ("Institutional predictive," 1968, p. 1).

In terms of continuing eligibility, the formula outlined noted Bowdoin's unique grading system-High Honors, Honors, Pass, Fail-rather than the traditional "A, B, C, D, F" letter system. In this system, "Pass" was defined as "satisfactory performance consistent with standards for graduation." Greason explained further that "grades are not averaged, because they have no numerical equivalents, but a student who receives a failing grade is usually ineligible for scholarship assistance." Greason further stated that "Without numerical equivalents, comparison is difficult, 
but it may be assumed that a student permitted to continue in college on scholarship is achieving a 1.6 minimum" ("Institutional predictive," 1968, p. 1).

While the amendment passed at the 1968 Convention afforded Bowdoin the opportunity to prove to the NCAA it was as academically selective as it claimed, thereby earning compliant status, initially it might have been presumed that Bowdoin's nontraditional grading system might have been the impediment in adhering to 1.600 . However, there was no discussion of the grading system as an issue in any of the correspondences between College officials and NCAA personnel pervious to Greason's 1968 communications. In addition, since this unique grading system was not formally adopted by Bowdoin until 1967 (Kolod, 1967), it would have no bearing on the Schulten case on or the College's initial actions against self-certification.

A week after Greason's telegram and letter were received, Byers wrote back to Greason to notify him that, based on the information provided, he was "pleased to confirm that Bowdoin College's policies and procedures satisfy the requirements of NCAA Bylaw 4-6-(b) and your institution is eligible immediately for NCAA events insofar as this legislation is concerned" (Byers, 1968, p. 1). Thus individual athletes were now free to resume championship participation. However, because of Bowdoin's participation in the Pentagonal Agreement, team sport athletes were still relegated to the sidelines.

\section{Discussion and Conclusions}

In his history of Bowdoin published by the College in 1993, historian Charles C. Calhoun noted "by the late 1960s, Bowdoin was a conservative, all-male, sportsminded college" (p. 232). Given that description, it would seem that such a "sportsminded" institution would revel in the fact that one of its own, Alex Schulten, could compete for an NCAA championship. Schulten was denied the chance to compete because Bowdoin's stated stand on the 1.600 Rule issue was based on the issue of institutional autonomy in the face of burgeoning NCAA control. But Calhoun's analysis is correct in the sense that Bowdoin was looking to bolster its athletic fortunes through the financial support of some recruited student-athletes via the awarding of athletic aid, a stance that it did not want to make public but was forced to address through the 1.600 certification process.

In the end, the NCAA was forced first to amend 1.600 then to replace it with the much less stringent 2.00 Rule. While Bowdoin officials worked for two years to pitch its position of exception to the NCAA, it is unclear if these efforts directly influenced any Association-wide efforts to amend and eventually to replace 1.600. It is possible to conclude that the Ivies and Bowdoin were chipping away at 1.600 from the stated public stance of usurped institutional autonomy, while others were claiming foul based on the issues of racial discrimination and impingement on recruiting.

At the 1973 Convention, where 1.600 was finally quashed, critics of the rule cited racial discrimination and loss of institutional autonomy (a claim Bowdoin made back in 1966) as rationale to dismantle 1.600. As a result, a new system was proposed, one that would merely require an athlete to have graduated from high school with a 2.0 or C+ average in any course of study, not necessarily one that focused on preparing a student to enter and to succeed in a traditional undergraduate program. The membership voted to repeal 1.600 by a slim 204-187 margin 
(Smith, 2011), and then opted to replace it with a weaker version, the " 2.0 Rule." The NCAA's Walter Byers regretted the change, commenting that the loss of 1.600 was "one of the most painful experiences" he had had while serving as the Association's head. "It was a terrible day for college athletics," when 1.600 was rescinded, he wrote (Byers, 1995, p. 165). The retreat from 1.600, combined with the declaration of freshman eligibility in 1972, led to many of the rules violations and abuses of the 1980s. Byers claimed the rule change lead to "a decade of mediocre academic values and free-handed recruiting" (Byers, 1995, p. 297). The 1980s would culminate by a renewed proposal for minimum academic standards for prospective student-athletes.

Of the ultimate impact of the short-lived 1.600 Rule on Bowdoin, the College continued to offer athletically related aid, while eventually submitting documentation that showed that all its students met the rule's criteria. It could be argued that the stance to fight the NCAA taken by Coles and the College was operationally prudent, for through these efforts Bowdoin was able to maintain its funding of certain student-athletes while maintaining publicly that it did not. When 1.600 was replaced with 2.00 , the case for academic certification became all the easier. Even though NCAA strictures did not restrict Bowdoin from giving athletic aid, the College's alliance with the three other schools in the Pentagonal Agreement meant that the NCAA's expansion of oversight forced College officials to respond to 1.600 in one of two ways: stop the aid or stonewall. They chose the latter.

The developments relating to 1.600 also pushed the NCAA membership to contemplate its' collective future. The Ivies and schools like Bowdoin had made pains to denounce publicly the implementation of 1.600 , as the measure had forced the schools to confront the covert issue of athletic aid. While it is true that Bowdoin never changed its approach to aid, the public nature of the conflict served to push Bowdoin closer to an enlarged and more codified conference affiliation.

It is also arguable that the 1.600 conflict also underscored the significant programmatic differences that had developed among member institutions. By the mid-1960s, especially in sports such as football, programs at schools like Bowdoin, which had emerged as short-lived powers back in the 19th century, had fallen far behind those fielded by the publicly supported institutions of the South, Midwest and West. In the years following World War II, the advent of television, the postwar economic expansion experienced across the country, rules changes such as open substitution, which allowed for even greater specialization and skill refinement among participants, as well as allowance of out-of-season practice sessions, led many programs across the country to realize the commercial opportunities and increased stakeholder interests associated with intercollegiate sport. While sport success was important to Bowdoin, the overt commercialized opportunities associated with intercollegiate athletics remained outside the school's mission and goals.

These changes, along with the approval of institutionally awarded financial aid based in athletic ability, served to widen gulf between the so-called "big time" programs and those at schools like Bowdoin. The 1.600 Rule was the NCAA's attempt at addressing the issue of initial academic eligibility through a one-size fits all approach. Ultimately, it can be concluded that the 1.600 issue was settled because even though Bowdoin wanted to sustain the operational functions that allowed it to be competitive among its peers, school administrators knew that leaving the NCAA was not a viable option. It is also clear that NCAA personnel were seeking 
ways to help keep the Ivies, Bowdoin and others in the fold, and made substantial accommodations to afford compliance with the rule.

The potential schism, combined with the environmental changes outlined above, would lead directly to an Association-wide restructuring through the creation of the three-tiered divisional classification system in 1973, which, among other factors, delineated the membership based on its approach to athletic aid. This segmentation, however, was predated by two years by the NESCAC Agreement, which brought the Pentagonals together with Bowdoin's old in-state rivals Bates College and Colby College, along with Hamilton, Middlebury, Trinity, Tufts University and Union College. Leaders at the Pentagonals had been mulling over requests from these and other schools for years to join their ranks, and the public disputes over 1.600 and the move to 2.00, and the implications of these NCAA mandates over athletic department goals and objectives relating to areas such as athlete eligibility and athletic aid, no doubt contributed to drive the Pentagonals to find a larger grouping in which to form competitive arrangements. While this new grouping served to define more broadly the direction and operation of NESCAC athletic departments, this expanded association would also experience several identity crises, namely the expulsion of Union College over recruiting and aid practices pertaining to its' men's ice hockey program, and conflicts relating to team sport participation in NCAA championships. As a result NESCAC would become a more closely knit conference, eventually embracing concepts such as full round-robin scheduling and conference championships to name NCAA postseason participants, mirroring aspects that were essential components of other such groupings.

With some variances, the concepts for initial eligibility for Division I and II student-athletes first established under 1.600 has been maintained under the tenets of Proposition 48, while Division III schools allow each individual institution to determine both initial and continuing eligibility. James Coles and his Bowdoin administrative colleagues would have no doubt approved of this ability for these schools to maintain this degree of institutional autonomy.

\section{References}

An interim agreement - press release (1967, February 20). Yale University News Bureau. Barnes, E.D. (1966, February 21). 19 ${ }^{\text {th }}$ hole: The readers take over. Sports Illustrated, p. 75. Barnett, V.M, Jr. (1966, February 10). Letter to James S. Coles, Bowdoin College president. Blankman, P. (1965, April 23). Polar bearings. Bowdoin Orient, p. 8.

Born, E. (1967, Fall). The Coles years. Bowdoin Alumnus, pp. 2-5

Bowdoin College Bulletin, Number 318. Sessions of 1955-1956. (1955, September). Brunswick, ME: Bowdoin College.

Bowdoin College Bulletin, Number 366. Catalogue for the sessions of 1967-1968. (1967, September). Brunswick, ME: Bowdoin College.

Bowdoin College Bulletin, Number 370. Catalogue for the sessions of 1967-1968. (1968, September). Brunswick, ME: Bowdoin College.

Bowdoin College will not subject its scholarship policy to NCAA control (1966, January 24). Bowdoin College News Service.

Bradner, Jr., J.H. (1966, March). Letter to Frank Sabasteanski, Bowdoin College track coach. Brewster, K. (1967, September 29). Letter to John E. Sawyer, Williams College president. Byers, W. with Hammer, C. (1995). Unsportsmanlike conduct: Exploiting college athletes. Ann Arbor, MI: University of Michigan Press. 
Byers, W. (1968, March 14). Letter to A.L. Greason, Jr., Dean of the College, Bowdoin College.

Calhoun, C.C. (1993). A small college in Maine: Two hundred years of Bowdoin. Brunswick, ME: Bowdoin College.

Coles, J.S. (1962, November 20). Letter to Robert C. Livingston, Oregon College of Education.

Coles, J.S. (1964, March 13). Letter to Richard T. Andrias, Representative, Bowdoin College Student Council.

Coles, J.S. (1966a, February 1). Confidential memorandum to Malcolm Morrell, athletic director, Bowdoin College.

Coles, J.S. (1966b, February 25). Letter to Everett D. Barnes, President, National Collegiate Athletic Association.

Coles, J.S. (1966c, August 8). Letter to John E. Sawyer, Williams College president.

Coles, J.S. (1966d, December 1). Memorandum to Bowdoin College Director of Financial Aid and Director of Admissions regarding establishment of the Arthur D. and Francis J. Welch Scholarship Fund.

Coles, J.S. (1967a, January 4). Letter to Victor L. Butterfield, Wesleyan University president, Calvin H. Plimpton, Amherst College president, John E. Sawyer, Williams College president.

Coles, J.S. (1967b, February 23). Letter to Marcus L. Plant, President, National Collegiate Athletic Association.

Coles, J.S. (1967c, March 3). Letter to Marcus L. Plant, President, National Collegiate Athletic Association.

Cross, R.M. (1987, September 11). Letter to A. LeRoy Greason, President, Bowdoin College. Dean reaffirms Bowdoin stand (1966, March 10). Portland (Maine) Press Herald, p. 22.

F. Alexis Schulten '66 (2009). Accessed September 19, 2010, from: http://athletics.bowdoin. edu/information/history/hall/schulten.

Falla, J. (1981). NCAA: Voice of college sports. Shawnee Mission, KS: National Collegiate Athletic Association.

Greason, A.L., Jr. (1968, March 7). Letter to Walter Byers, Executive Director, National Collegiate Athletic Association.

Helman, J.W. (1989). A history of American intercollegiate academic eligibility: Educational compromises to competitive interests. Unpublished doctoral dissertation, Pennsylvania State University.

Honor system, sports ban discussed by Council (1964, February 14). Bowdoin Orient, p.1. Institutional predictive formula for freshmen (1968, February 2). Office of the Dean of the College, Bowdoin College.

Ivy League drops out of all N.C.A.A. championships (1966, March 6). New York Times, p. 5-1. Ivy League to accept N.C.A.A. academic norm (1966, February 24). New York Times, p. 16.

Kendrick, N. C. (1966, June 17). Responses to survey from ECAC Executive Council anent NCAA 1.600 legislation.

Kolod, A. (1967, September 29). Faculty ends letter grades; "C" rule, warnings out; Pass-fail possibly seen. Bowdoin Orient, pp. 1, 3.

Litsky, F. (1966, March 11). 2-day track meet will open today. New York Times, p. 15.

Morrell, M.E. (1946, February 26. Letter to Bowdoin President Kenneth C.M. Sills.

Morrell, M.E. (1955, November 11). Letter to James S. Coles, Bowdoin College President.

N.C.A.A. championships are slated for next week (1966, March 6). New York Times, p. 8.

N.C.A.A. Council-sponsored amendment to 1.600 Rule (1967, November 30). National Collegiate Athletic Association.

New "triple option" may be submitted (1978, June 1). NCAA News, p. 4.

Pappas, P., \& Graham, G. (1964, September 25). Polar bearings. Bowdoin Orient, p. 6. Pentagonal conference uphold post-season rule (1962, March 1). Bowdoin Orient, p. 1

Plant, M.L. (1967a, March 1). Letter to James S. Coles, Bowdoin College president. 
Plant, M.L. (1967b, December 1). Special memorandum to Chief executive officers, faculty representatives and directors of athletics on the subject of Council-sponsored amendment to 1.600 legislation.

Report of the President's Commission on athletics (1972, June 1). Bowdoin College.

Revolt in the ranks (1966, March). Bowdoin Alumnus, p. 5.

Rice, M.F. (1966a, March 4). The Associate's Corner. Bowdoin Orient, p. 4.

Rice, M.F. (1966b, March 11). The Associate's Corner: The NCAA controversy. Bowdoin Orient, p. 4.

Sack, A.L., \& Staurowsky, E.J. (1998). College athletes for hire: The evolution and legacy of the NCAA's amateur myth. Westport, CT: Praeger.

Sawyer, J. E. (1967, January 16). Letter to James S. Coles, Bowdoin College president.

Smith, R.A. (2011). Pay for play: A history of big-time college athletic reform. Chicago: University of Illinois Press.

Stuckey, D.K. (1968, January 15). Letter to Athern Daggett, Bowdoin College acting president.

Thelin, J. (1996). Games colleges play: Scandal and reform in intercollegiate athletics. Baltimore, MD: Johns Hopkins University Press.

Thoms, Jr., F.R. (1964, June 18). Memorandum to John E. Sawyer, Williams College president regarding June 1, 194 meeting of athletic directors of Amherst, Bowdoin, Wesleyan and Williams.

Tiede, J.S. (1966, July). Letter to Editor. Bowdoin Alumnus, p.1.

Watts, C.H. (1966, February 7). Letter to James S. Coles, Bowdoin College president.

White, G.S., Jr. (1966, February 18). N.C.A.A. gives 57 colleges extension on scholastic code. New York Times, p. 14. 